DOI: 10.17805/trudy.2015.2.7

\title{
МОСКОВСКИЙ ГУМАНИТАРНЫЙ УНИВЕРСИТЕТ СТАЛ ЛАУРЕАТОМ ВСЕРОССИЙСКОГО КОНКУРСА «100 ЛУЧШИХ ВУЗОВ РОССИИ»
}

\author{
Б. Н. Гайдин \\ (Московский гуманитарный университет)
}

\begin{abstract}
Аннотация: В статье представлено очередное достижение Московского гуманитарного университета 2015 г. - звание лауреата номинациях «Лучший негосударственный вуз» и «Лучшая профильная кафедра» Всероссийского конкурса «100 лучших вузов России».

Ключевые слова: Московский гуманитарный университет, негосударственный вуз, всероссийский конкурс, «100 лучших вузов России».

\section{MOSCOW UNIVERSITY FOR THE HUMANITIES HAS BECOME A LAUREATE OF THE NATIONAL CONTEST "RUSSIA'S TOP 100 HEIS"}

\author{
B. N. Gaydin \\ (Moscow University for the Humanities)
}

\begin{abstract}
The article is devoted to the latest achievement of Moscow University for the Humanities. In 2015 at the national contest "Russia's top 100 HEIs" it was awarded laureateship in two nominations, as "Best non-state-run university" and "Best profile department".

Keywords: Moscow University for the Humanities, non-state-run university, national contest "Russia's top 100 HEIs".
\end{abstract}

Московский гуманитарный университет в 2015 г. стал лауреатом Всероссийского конкурса «100 лучших вузов России» в номинациях «Лучший негосударственный вуз» И «Лучшая профильная кафедра». Итоги конкурса подводились в Санкт-Петербурге в рамках VIII Всероссийской конференции «Проблемы и перспективы развития высшего образования и науки в Российской Федерации», прошедшей 17-19 апреля 2015 г.

Прошедший в Северной столице образовательный форум ставил важные вопросы, волнующие сегодня ректоров, преподавателей и студентов вузов. В конференции участвовали представители ведущих вузов из разных регионов страны, заместители председателей профильных комитетов Государственной Думы доктор физико-математических наук, 
академик РАЕН В. Шудегов, доктор философских наук О. Смолин, доктор медицинских наук, академик РАН В. Черешнев и другие.

На церемонии вручения наград, прошедшей в конгресс-отеле «Park Inn Прибалтийская», от МосГУ присутствовала проректор по научной работе, доктор педагогических наук, профессор Л. В. Романюк.

Кроме МосГУ в список «100 лучших вузов России» вошли такие известные по всей стране учебные заведения, как МГУ им. М. В. Ломоносова, Московский физико-технический институт, Высшая школа экономики, Санкт-Петербургский государственный политехнический университет, Санкт-Петербургский государственный университет, МГИМО, Московский государственный технический университет им. Н.Э. Баумана, Российский университет дружбы народов, Российский экономический университет им. Г. В. Плеханова и др.

Лауреаты были определены экспертным советом, состоящим из Независимого общественного совета при участии профильных комитетов Государственной Думы РФ и Совета Федерации РФ, институтов Российской академии наук, Российских академий образования и естественных наук.

Победителям конкурса торжественно вручались дипломы и золотые медали. Кроме того, руководители высших образовательных учреждений еще получили в награду золотой знак «Ректор года», а директора НИИ, проектных, конструкторских и технологических организаций были удостоены знака «Ученый года».

Председатель оргкомитета мероприятия - президент Международной академии качества и маркетинга, главный редактор журнала «Профессия - директор» Раиль Кашапов, говоря о ставшем уже традиционным в России конкурсе, отметил, что его основной целью является поддержка усилий руководителей государственных и негосударственных вузов, институтов Российской академии наук, а также проектных, конструкторских и технологических организаций страны по развитию передовых и инновационных технологий и совершенствованию научных исследований и разработок. Для изучения успешности работы вуза оргкомитетом разработана «Модель оценки вуза», которая включает в себя ряд основополагающих критериев. А оценка НИИ, проектных, конструкторских и технологических организаций России базируется на их способности реализовывать задачи, соответствующие современным требованиям технологического и промышленного развития.

МосГУ в этом престижном Всероссийском конкурсе не впервые отмечается. По итогам VI Всероссийского конкурса «100 лучших вузов России» в 2013 г. Московский гуманитарный университет занял первое место в номинации «Лучший негосударственный вуз»; победителем в номинации «Лучший НИИ вуза» стал Институт фундаментальных и прикладных 
исследований Московского гуманитарного университета; в номинации «Лучшая научная книга года» дипломы лауреатов получили ректор МосГУ, доктор философских наук, профессор И. М. Ильинский за книгу «Прошлое в Настоящем» и проректор МосГУ, директор ИФПИ МосГУ доктор философских наук, профессор Вал. А. Луков - за монографию «Теории молодежи: междисциплинарный анализ».

Лучшей профильной кафедрой Всероссийского конкурса «100 лучших вузов России» в 2015 г. была признана кафедра теории рекламы и массовых коммуникаций Московского гуманитарного университета (заведующий - кандидат исторических наук, доцент Е. Л. Головлева). Это выпускающая кафедра факультета рекламы Московского гуманитарного университета по специальности «Реклама», направлениям подготовки бакалавриата и магистратуры «Реклама и связи с общественностью». Кафедра образована в июле 1996 г. За прошедший период ее деятельности более двух с половиной тысяч студентов защитили выпускные квалификационные работы и получили высшее образование в области рекламы и связей с общественностью. Многие выпускники кафедры представлены в ведущих агентствах рекламной индустрии. Лучшие из них получают рекомендации для поступления в аспирантуру. Они могут защищать кандидатские диссертации по научным специальностям в области экономики, социологии, философии, культурологии и др. За последние годы диссертации защитили: О. Власова (Мацкевич) - по психологии, А. Сафарян и И. Маркин - по социологии. В 2010 г. Гильдия экспертов в сфере профессионального образования. Национальный центр общественнопрофессиональной аккредитации, журнал «Аккредитация в образовании» наградили кафедру за «Лучшие образовательные программы инновационной России» в части рекламы.

Учебная работа кафедры теории рекламы и массовых коммуникаций Московского гуманитарного университета ориентирована на компетентностный подход в определении содержания учебных дисциплин и организации практик. Коллектив кафедры разработал 79 профильных учебных курсов, обеспеченных оригинальными программами, учебными пособиями и фондами оценочных средств по направлению / специальности реклама и связи с общественностью. Преподаватели кафедры с участием представителей рекламной индустрии подготовили и издали более сорока авторских учебников и учебных пособий по различным дисциплинам. Кафедра располагает фундаментальными трудами Е. Л. Головлевой «Основы рекламы», «Массовые коммуникации и медиапланирование», «Торговая марка», «Международная реклама»; Е. Л. Головлевой и P. T. Мухаева «GR: модели коммуникации власти и групп интересов», «Стратегии и технологии самопродвижения», И. А. Гольмана «Рекламная 
деятельность. Планирование. Технологии. Организация» Э. А. Смирнова «Управленческие решения», М. Л. Сосновой «Креативные решения в рекламе», Н. Н. Грибок и Л. В. Мрочко «Реклама и связи с общественностью в социальной сфере» и др. По заказу Министерства образования и науки кафедра теории рекламы и массовых коммуникаций является разработчиком первой базы тестовых заданий по дисциплине «Основы рекламы» для российских вузов.

Кафедра обеспечивает информирование студентов о требованиях по освоению каждой учебной дисциплины, обратив внимание на допустимый минимум освоения и возможности ее углубленного изучения, предлагают студентам современные учебно-методические разработки. Уважительное отношение к студенту, заинтересованность в его успешной учебе стало характерным во взаимодействии преподавателей и студентов.

В январе 1996 г. состоялась первая зарубежная стажировка студентов факультета во Франции по приглашению ААСС (Ассоциации агентствсоветников по коммуникации Франции) «Современная французская реклама: практика регулирования». Преподаватели факультета занимаются воспитательной работой со студентами, заинтересованно отслеживают проблемы освоения знаний студентами, принимают соответствующие меры по их сопровождению в учебном процессе, оказанию своевременной помощи. Учебно-воспитательный процесс на кафедре обеспечивает высококвалифицированный состав преподавателей. В учебном процессе участвуют ведущие специалисты из рекламной и PR индустрии: генеральный директор PR-агентства Е. Н. Якутина; руководитель социологического отдела аналитического центра компании Видео Интернешнл, д. с. н., профессор И. А. Полуэхтова; директор по работе с клиентами и новому бизнесу компании Advance Digital A. C. Коцюба, креативный директор Галереи «Арт-Гнездо», главный редактор журнала «Новый коллекционер», профессор И. А. Гольман; генеральные директора коммуникационных агентства (А. Е. Назарюк, М. Ю. Климанов, Б. Маилин, О. Н. Мошеева и другие).

Научная деятельность кафедры развивается в нескольких плоскостях, которые в общем плане можно определить как продвижение студенческой науки, стимулирование и создание условий для участия преподавателей в научно-исследовательской работе. Кафедра работает над развитием научной школы по проблемам когнитивных стратегий и технологий коммуникации. Ставится научная задача разработки методологии и механизма конструирования коммуникативных стратегий, технологии создания новых поведенческих установок (в компании, государственной структуре, общественной организации) на основе сравнительного анализа различных культурных сред. Кафедра выполняла гранты российских научных фондов на темы: «Влияние рекламы на языковое сознание мо- 
лодежи» (РГНФ), «Истоки стратегических образов современной России и особенности их продвижения на инокультурные аудитории» (РГНФ). Научные задачи и интересы кафедры реализуются в научных публикациях преподавателей. За последние три года опубликовано более 70 научных статей, изданы монографии Е. Л. Головлевой «Реклама в формировании современных коммуникативных практик (на материалах США, Западной Европы, Японии)» (2014), Е. Л. Головлевой т Р. Т. Мухаева «Информационная политика и информационное поведение: тренды, стратегии, технологии: монография» (2015), Л. В. Мрочко «Корпоративная культура коммуникационного агентства» (2014) , «Реклама в XXI веке: современные тренды: отв. ред. Р. Т. Мухаев (2014), «Коммуникативные стратегии личностной и корпоративной репрезентации: монография /под общей ред. Е. Л. Головлевой (2013), А. Д. Бородая, Н. Н. Грибок «Становление и развитие индустрии рекламы в России» (2012). Кафедра участвует в конкурсах на получение грантов российских научных фондов. Проведено полевое исследование на тему: «Влияние рекламы на языковое сознание молодежи (РГНФ, №07-04-94507е/Я), реализован проект на тему: «Истоки стратегических образов современной России и особенности их продвижения на инокультурные аудитории» (РГНФ, № 09-03-00770 а/Р).

Гайдин Борис Николаевич - кандидат философских наук, заместитель директора Центра теории и истории культуры Института фундаментальных и прикладных исследований Московского гуманитарного университета. Адрес: 111395, Россия, г. Москва, ул. Юности, д. 5, корп. 6. Тел.: +7 (499) 374-59-30. Эл. адрес: barbarious@mail.ru

Gaydin Boris Nikolaevich, Candidate of Philosophy, Deputy Director, Center for the Theory and History of Culture, Institute for Fundamental and Applied Studies, Moscow. Postal address: Bldg.6, 5 Yunosti St., 111395 Moscow, Russia. Tel.+7 (499) 374-59-30.Email: barbarious@mail.ru 